\title{
Documentos
}

María Zambrano

\section{Un descenso a los infiernos}

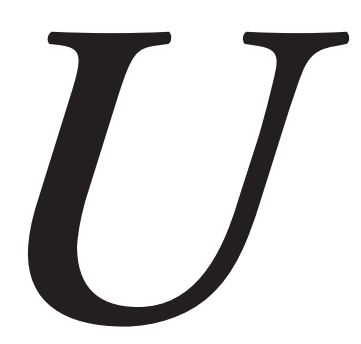

n signo inequívoco de que estamos en el umbral de una nueva época, quizá de un nuevo mundo, es la necesidad y aún las parciales realizaciones de ese viaje que el hombre se ha visto siempre precisado a cumplir: el descenso a los infiernos. A sus propios infiernos. Infierno de la propia alma individual, infierno de la Historia poblada de ellos. Pues la historia, integrada por los pueblos e ideas victoriosas, condena a los otros, los vencidos, a quedar enterrados vivos, viviendo, sí, mas sin espacio para su alma, sin la luz adecuada. Todo lo que vence humanamente parece estar condenado a condenar y, al fin, a condenarse.

De ahí el contrapeso que oponen siempre de la Historia la poesía y la filosofía, "saberes de salvación”, como diría Max Scheler. Sin la Historia y su cortejo de vencedores y vencidos quizá un solo poema -Filosofía y Poesíahabría sido suficiente para todos los hombres. Mas al no ser así, la palabra se vuelve necesaria, en dos formas que corresponden a dos situaciones fundamentales de los protagonistas del juego histórico: las razones justificadoras del que vence; las razones liberadoras del vencido. No es un azar que la cultura de Occidente venga desde hace tiempo justificándose y padezca la obsesión de la legitimidad. Legitimarse es la tarea de los que han ganado la batalla de una época.
Pero no basta; lo de momento vencido clama: que clamar es la fatiga de todo enterrado vivo, y toda realidad condenada se levanta un día por esa maravillosa voz libertadora poética y aún razonadora.

La Filosofía ha ido dejando a la poesía esa función redentora de lo que gime condenado. No fue así siempre. En el momento actual tenemos todos esos intentos, de vitalismo y existencialismos, que claman, por una amplia, totalizadora razón vital que dé cuenta de todo lo que quedó apresado por la legitimidad victoriosa o de los victoriosos.

Desde el Romanticismo se han ido verificando diversos descensos a los infiernos; infiernos del alma asfixiada, de lo no dicho, de lo imposible de expresar, de la blasfemia misma. ¿Qué se oculta en la blasfemia? ¿Qué, en el sacrilegio? ¿Quién tiene en definitiva la culpa? ¿Y esa defensa del culpable que tiende a ganar el ámbito de toda razón justificante, pues, al fin, el condenado nos condena, o nos condenamos por él? En todo caso, una visita a los infiernos parece obligada; una larga, lúcida visita a todos sus laberintos infernales donde el bien y el mal presentan otras caras, y todo parece intercambiable; donde las definiciones racionales y establecidas pierden su vigencia; donde todo lo que se sabe se olvida, porque lo olvidado vuelve y se presenta en una memoria continua, sin principio, ni fin: sin punto de referencia. 
Viaje como un sueño lúcido es el que el poeta Octavio Paz nos lleva a realizar a través de su libro El laberinto de la Soledad'. Tiene del sueño ese contacto íntimo con la realidad, del que se sale al despertar y que, aunque se trate de una realidad pavorosa, nos produce la impresión de haber abandonado el hueco exacto de nuestro ser, donde reside la verdad de nuestra vida: el lugar de nuestro infierno, que es el mismo de nuestro paraíso. Llevarlo a la vigilia, sin que se esfume ni se debilite su palpitación; hacerlo visible, sin que pierda su obscura vida, es acción que solo la poesía que sea al par pensamiento, puede realizar.

Filosofía y poesía en íntima unidad nos ofrece este libro de un poeta cuya poesía ha estado siempre traspasada de pensamiento. Raíz del hombre es, en realidad, el título de todos sus poemas: la búsqueda, la persecución de lo humano.

En virtud de ese radicalismo que es el carácter común de toda la Filosofía moderna, la pregunta por lo humano ha estado condicionada por una definición o, al menos, una aceptación previa de lo humano, por un saber antes de saber. Materialismo e idealismo han tenido este común punto de partida, diríamos "idealista", que consiste en dar por supuesto lo que se iba a buscar y, lo que es más grave todavía, el horizonte que lo encierra. Más, por otra parte la soledad, la profunda soledad en que el hombre se ha ido quedando a partir del Renacimiento, ha hecho necesario el encuentro del hombre consigo mismo. Y así, la época moderna podría quedar definida por esta persecución que cada vez de modo más encarnizado realiza el hombre frente al hombre. Persecución que se inicia en el ámbito del conocer y que ha desembocado en la acción, hasta culminar en esa pasión persecutoria que ocupa casi por completo el escenario de nues- tra época. No es necesario hoy ningún agente que dirija este infierno creado por el hombre en su angustiosa persecución de sí mismo, para tenerse al fin entre sus manos, por saber quien es, sin intermediario de idea, ni de imagen alguna. De allí que el "a priori” del pensamiento haya sido abandonado por la Filosofía misma, que hoy pretende no partir de supuesto alguno, sino de la radical angustia del ser humano en la soledad. Mas tal tarea, urgente cuanto es urgente que la persecución inacabable cese, ha de ser aventura en las más íntimas capas del ser: acercamiento obscuro, poético, a la raíz del hombre.

Octavio Paz, en su obra poética, se ha aproximado a esta raíz, así, ha tenido que realizar esa ascesis difícil para un poeta, que es librarse de las imágenes. Las imágenes en esta ocasión llevarían consigo la caída en aquello que se quería evitar: en el narcisismo. La poesía de Octavio Paz, su acercamiento a la Raíz del hombre, ha sido una aventura llevada a cabo por una poesía desnuda, que rechaza cuanto le es posible la imagen como fruto último y que es aspiración profunda al pensamiento. Raro momento de la poesía, no señalado aún que sepamos, y que constituye algo muy esencial en el mundo de la poesía en idioma castellano, donde esta aventura de la soledad del hombre no ha sido apurada. Hay dentro de la lírica española actual, ocultos quizá por el esplendor de poesía menos problemática dos poetas que se han adentrado en este difícil, obscuro camino: Emilio Prados y Luis Cernuda. Con la obra de los dos, más estrechamente con la de Cernuda, la del mexicano Octavio Paz tiene un íntimo parentesco, que le adviene no de las llamadas "influencias", sino de estar situada ante la misma realidad: la realidad del hombre no definida, antes de haber sido sometida a la manipulación del pensamiento o a cualquier abstracta reducción de la mente.

\footnotetext{
${ }^{1}$ Fondo de Cultura. 4a edición. 1964.

${ }^{2}$ México, 1937.
} 
La sorpresa de encontrarnos ante un libro que es Filosofía y poesía en unidad tan íntima como El laberinto de la Soledad proviene del asombro que se siente ante algo logrado, sin mezcla alguna de extrañeza. Sorprende, pero no extraña. El pensamiento apetecido tenía al fin que aparecer, como lo ha hecho, sin desprenderse de la actitud que lo originó, de la misma actitud de Raíz del Hombre: ir al encuentro de lo humano, sin determinar previamente su contenido, ni el horizonte en que aparece.

A primera vista nos encontramos en $E l$ laberinto de la Soledad ante una cierta vacilación: ¿se trata de Poesía o de Filosofía? Mas pronto advertimos que idéntica pregunta se formula ante todos los relatos de los viajes a los infiernos. En el más ilustre de todos hay hasta Teología. No puede dejar de haberla si se quiere llegar hasta las postrimerías, a las fronteras últimas de las situaciones esenciales de la vida humana. Un viaje a los infiernos ha de ser cumplido por la piedad y la razón unidas, pues sólo a esa unidad indiscernible se entreabren las profundidades infernales. La razón sola se detiene en el límite de lo razonable: su propia sombra. Es cosa olvidada que el horizonte, el lugar por donde la razón puede dejar caer su luz, no está dado por ella, sino en esos límites, isla de lo racional rodeada de irracionalidad. Abandonar la seguridad que se goza en esa isla dócil a la evidencia, es obra de la piedad, que no es simple compasión (piedad en el más moderno de sus sentidos), sino la sabiduría de saber tratar con "lo otro", con lo heterogéneo. Con "lo otro" de la razón y que no por ello deja de constituir lo real. Y así, la piedad, como el amor, hace a la razón trascendente ser trascendente: entrar en realidad. Sólo las nupcias de la razón y de la realidad producen el conocimiento. En las profundidades de la vida la realidad no revelada o condenada, impone su ley con más fuerza, pues es mayor su resistencia y aún, podría decirse, su rencor. Solo esa diplomacia de la piedad la hace accesible. No ante una razón sin más, los infiernos se abren de manera tal que quien entre pueda salir, sin quedar su prisionero.

Al decir infierno, usamos un nombre, damos un nombre aquí a lo sagrado. Porque es de lo sagrado, en toda la plenitud del término de lo que la poesía pensamiento de Octavio Paz nos revela el secreto laberinto. Y así encontramos que es poesía, poética, la acción: filosófico, el hallazgo. En ciertas situaciones, para que el pensamiento se realice hace falta una actitud poética más que filosófica. Descender a los infiernos exige una inteligencia en estado de gracia. Así, esa pura transparencia que nos ofrece El laberinto de la Soledad.

Filosofía y poesía en unidad nos presenta este libro de un poeta, cuya poesía ha estado siempre traspasada de pensamiento.

Pero dentro de esta unidad se distingue el gesto poético de la entrega, de la ofrenda, en suma, de la actitud y de la acción, diríamos, intelectual o propiamente filosófica. El laberinto de la Soledad es un libro de filosofía ofrecido poéticamente. A diferencia de la Filosofía, la Poesía se ofrece sin anunciarse a sí misma, sin exigir, por tanto, una especial actitud del lector, en cuya mente se desliza sin preparativo alguno.

El pensamiento guiado por la piedad ha de forjar sus categorías en una forma poética. ¿Existen, acaso, categorías poéticas, que serían, a diferencia de las de la razón, categorías de la vida viviente? Eso es lo primero que Octavio Paz se hubiera planteado y hubiera anunciado que iba a hacer, si su libro entrara en la clase de esos llamados "Aportaciones al estudio de" o si, con más decidida audacia, lo hubiera lanzado con la pretensión de edificar, ya que no un sistema, un preludio o un esbozo. Lejos de hacerlo así, se adentra en la realidad directamente, con simplicitud. La realidad que nos ofrece $E l$ laberinto de la Soledad es la del hombre habitante de México, en toda su desnudez y soledad. Las "categorías de vida", que Octavio Paz 
descubre, son categorías de lo sagrado. No estamos en el mundo de los efectos y las causas, como tampoco en el del principio de contradicción; estamos en el laberinto de la soledad humana, un lugar sagrado entre todos. Y como el mundo de lo sagrado es el de la cualidad, "abierto" y "cerrado" marcan situaciones antagónicas. Cerrado es la situación del hombre en su integridad: "hombre", si alguna definición cabe, es aquel que no ha cedido. Abrirse es ceder, someterse - dice Octavio Paz -. En lo que advertimos la radical desconfianza frente a una realidad a la que no se pueda dar acogida, ante la que no se pueda ceder, sin quedar sometido. Desconfianza radical que sólo puede referirse a una realidad radical. ¿Cómo pondría en relación Octavio Paz esta desconfianza determinante de la soledad con los Dioses que cubren el cielo mexicano? "Todo cambio histórico es un cambio de Dioses", dice. Esta situación puede definirse tal vez diciendo que el mexicano vive bajo el eclipse de Dios, en un momento en que sus Dioses parecieron abandonarlo y el nuevo Dios no ha engendrado la apertura del hombre. El hombre ofrece así resistencia a lo sagrado. Estar cerrado es resistir. La apertura es siempre una herida.

Son la llamadas "entrañas" las que no pueden abrirse sin quedar heridas $y$, al quedar al descubierto, afrentadas. Las entrañas son aquello que no puede abrirse, al menos, directamente; ha de hacerse siempre a través del corazón, y el corazón a través del alma. Poseer un alma era la máxima esperanza de los hombres de antiguas culturas. En la egipcia sólo el privilegiado Faraón nacía con ella, lo que quizá se encuentre en relación con ser hijo directo del Sol, es decir, hijo de la luz. Para que las entrañas se abran sin ofensa es necesaria una cierta relación con la luz. Y esto envuelve, a su vez, otra metáfora: la metáfora de la ley, de la paternidad que ampara y representa un mundo de equidad, de justicia.

Tal modo de vivir implica el haber entrado plenamente en la Historia, el haber nacido a la lucha y a la convivencia. El hombre apegado a la soledad, el "pachuco" que nos presenta Octavio Paz, parece resistir a esa luz que penetra sin humillar. Quizá porque sabe obscura y ciertamente -la certidumbre no es siempre clara- que ello significa nacer. Y nacer es estar comprometido en el juego de la historia. Ciertamente, el quehacer humano es la historia, y no es posible vivir humanamente sin hacerla y padecerla. Pero en ese hombre mexicano preso en su laberinto, resulta evidente la resistencia a la historia, su hermetismo ante la forma del vivir histórico. No ante esta época o este modo de historia, ante esta o la otra cultura, sino ante toda historia. Cuando recordamos que el hombre occidental se ha volcado en la historia con más furia e intensidad que hombre alguno, bien podemos interpretar esa actitud de resistencia -que nos hace visible este tan poético análisis, visión más bien, de El laberinto de la Soledad- como una resistencia ante la historia más histórica del mundo. Este hombre, heredero de viejísimas culturas entrañables, en las que el hombre se "abría" ofreciendo su corazón en aliento a un Dios, ahora se "cierra" antes de comprometerle y arriesgarse a perderlo en ese otro laberinto: el de la historia.

En el Laberinto de la historia lo que gime aprisionado parecen ser esas entrañas que sólo por mediación del alma pueden afrontar la luz. La cultura victoriosa de Occidente abandonó hace tiempo el alma y con ella -lo que quizá no soñó- ese mundo obscuro, hermético, que no puede abrirse directamente, porque toda apertura resulta una herida y una afrenta. Vivir desde la conciencia ha sido y es aún la exigencia de la vida occidental, de la razón triunfante. Mas hemos llegado al punto en que la conciencia y la razón se ven obligadas a corregirse a sí mismas. La confianza que nace de la desconfianza desconfía de sí misma y la Razón examina su propia estructura. Los mundos sumergidos aparecen. Para la cultura desalmada de Occidente ha llegado al momento inevitable de rendir cuentas, aunque no se 
sepa a quien, aunque crea hacerlo sólo ante las propias exigencias de su mente o simplemente forzada por la necesidad de salir del laberinto histórico.

El laberinto al que nos introduce Octavio Paz en su libro nos aparece así un verdadero laberinto, un lugar secreto, sagrado: todo eso gime y palpita en el interior del interior del hombre: en el fondo último de un corazón humillado y ofendido y que quizá sea quien inevitablemente nos juzgue; la medida suprema de toda cultura, la viviente realidad más allá de toda ley. Lo que constituye el infierno porque hubiera podido ser el formulado Paraíso. Según el Libro de los Muertos del antiguo Egipto, la momia sufría el ser juzgada primero por el corazón de la madre; el corazón de la madre, el propio corazón, la "raíz del hombre". Parece inevitable recordarlo ante toda la obra poética de Octavio Paz y ante este libro en que nos ofrece desnudo, apenas desprendido de su obscuridad temblorosa, una herida que no parece ser de nada, sino de este "corazón de la madre" que se entrega a la muerte, con la esperanza recóndita quizá de volver a nacer en una vida sin ofensa.

El corazón vive secretamente, obscuramente y sin embargo, o quizá por ello, demande la entrega. Alcanza la plenitud sólo cuando se da, cuando se ofrece. En la antigua Religión azteca se practicaba el sacrificio humano y era el corazón lo que se extraía de la víctima para ser ofrecido al Dios. Acción que muestra en su realidad horrificante la doble relación del hombre con sus Dioses; que los Dioses se ali- mentan de las humanas entrañas y que ellas mismas aspiran a ser consumidas por algo divino, como muestra siempre la mística cristiana y de cualquier Religión luminosa. Por mi parte me pareció encontrar en tierras de México una especie de nostalgia del sacrificio humano, como clave última de todas las formas en que el mexicano entrega su vida por... porque si, por nada. Esta nada puede ser el vacío de los antiguos Dioses desaparecidos no sustituido -en el corazón del hombre- por la imagen del Dios nuevo. De todo el libro de Octavio Paz -de este y de todos los suyos- se desprende esa atmósfera de sacrificio, esa luz amarillenta que yo he visto en México a la caída del sol, dorando las casas, envolviendo la cabeza del indio, señalando el perfil del horizonte. Luz sagrada, de sacrificio, en que el sol se despide de la tierra quizá con insatisfacción de llevarse su alimento. Y me pareció sentir que morían y mataban por eso, porque el sol no traspusiera solo el horizonte.

Plenamente occidental y aún moderno en sus formas, en su lenguaje, Octavio Paz ha logrado que de cuanto escribe se desprenda esta luz que pide sacrificio de su México. El laberinto de la Soledad nos ofrece la imagen de uno de esos templos, vacíos hoy, donde el indio desamparado entra en busca de sacrificio. Pues sacrificio es, quizá, la palabra clave de todo laberinto humano descifrado. Es no sólo la idea, sino su alma y su cuerpo, su sabor, lo que nos deja este libro de Octavio Paz.

María Zambrano 